Sustinere

Journal of Environment and Sustainability

Volume 2 Issue 3 (2018) 108-117

Print ISSN: 2549-1245 Online ISSN: 2549-1253

Website: https://sustinerejes.comE-mail: sustinere.jes@iain-surakarta.ac.id

\title{
RESEARCH PAPER \\ Adaptation and mitigation strategies in the transportation sector to reduce the greenhouse gases emission in Batu City
}

\author{
Juwita Amanda Lestari*, Rachmat Boedisantoso, Abdu Fadli Assomadi \\ Department of Environmental Engineering, Institut Teknologi Sepuluh Nopember, Indonesia \\ Article history: \\ Received 10 August 2018 | Accepted 14 December 2018 | Available online 31 December 2018
}

\begin{abstract}
The increased number of tourists in Batu City has resulted in traffic congestion, which led to the increase of emission contributing to GHGs effect and caused global warming. According to Presidential Regulation Number 71 of 2011, each region is required to conduct a national inventory of GHGs emission, in order to determine the appropriate adaptation and mitigation strategies in reducing the GHG emission. This research aimed to reduce the GHGs emission and to determine the appropriate adaptation and mitigation strategies in Batu City especially in the transportation sector. IPCC Guidelines 2006 was used as the method to calculate GHGs emissions. Such method allowed the researchers to determine the emission level by using secondary data obtained from the relevant institution. Determination upon adaptation and mitigation strategies was on the basis of several scenarios of emission level reduction while the prioritized strategy selection was based on the Analytical Hierarchy Process method. This research revealed that the GHGs emission with business as usual scenario in 2030 contributed by transportation reached 2,072.64 $\mathrm{Gg}$ of $\mathrm{CO}_{2}$ while the greatest reduction of GHG emissions amounted to $-6.13 \%$ taken from the scenario of Intelligent Transport System application. More importantly, the researchers figured out that the prioritized adaptation strategies should be the improvement of Urban Open Space and public transportation rejuvenation for the mitigation.
\end{abstract}

Keywords: adaptation; emission; greenhouse gases; mitigation; transportation

\section{Introduction}

Batu City is one of the regions in Indonesia, which focused the development in the tourism sector as its development function (Budiyanto, 2010). Furthermore, the tourism activities in Batu City are continuously increasing annually. According to the Central Bureau of Statistics of Batu City, in 2016, the tourist-oriented region was more considerably visited compared to 2015 . It was recorded that in the 2016's total visit increased by approximately $7.67 \%$ from the

*Corresponding author. E-mail: juwitaamandal@gmail.com

DOI 10.22515/sustinere.jes.v2i3.68 
previous year. The increased number of tourists could cause traffic congestion and might affect the neighbouring environment (Nurhidayati, 2009).

The increase in traffic congestion was caused by the need for transportation which then increased the exhaust gas of vehicles. The emission of exhaust gas from vehicle produced air pollution which could decrease the quality of air and threat human's health (Adak et al., 2016). Transportation has become a significant sector that contributes to the increase of carbon emission which was projected to $10 \%$ per year (Boedoyo, 2008). The combustion of carbon from fossil fuel in transportation produces carbon emission, which contributes GHG to the atmosphere. Zhang et al. (2013) stated that land transportation became the biggest resource of GHGs, which contributed $77 \%$ of total transportation emission that mostly came to private cars.

Any effort to decrease of GHG emission in transportation sector becomes the crucial topic in global effort to reduce the impact of climate change in line with Presidential Regulation Number 61 of 2011 on National Action Plan of Greenhouse Gasses Emission Reduction. This regulation then forces each local government, in this case in the regional or city level, to conduct an inventory of GHG emission regulated in Presidential Regulation Number 71 of 2011 on the Implementation of National GHG Inventory. This is conducted to provide information relating to the emission level, which becomes the information about the quantity of GHG emission on an annual basis. The profile of GHG emission level is used as the basis of the projection of GHG in the following year by using Business As Usual (BAU) scenario. BAPPENAS (2012) BAU scenario provided an assumption of the tendency of future development similar to the previous years, or none of the policy needs to be amended.

The result of GHG emission inventory with BAU scenario describes the increase of GHG emission each year. Such annual increase may affect the climate system so the earth's temperature and sea level will increase too. In order to stabilize the number of GHG emission concentration in the atmosphere in the safe level, a GHG emission level program in the atmosphere must be conducted (BAPPENAS, 2012). Such a program is considered an investment, which means that the cost spent recently, which aims to avoid the risk of greater disaster in the future, is determined as prevention upon the impact of climate change.

The program of GHG emission reduction needs to be supported by the adaptation and mitigation strategies as the part of the National Action Plan of GHG contribution performed by Batu City so that the target could be well determined. Adaptation and mitigation strategies are performed to decrease the impact of climate change by finding any means to slow down or hold the GHG emission (Klein \& Huq, 2007). This research, concerning the determination of adaptation and mitigation strategies in the transportation sector, applied Analytical Hierarchy Process (AHP) method. Such method was expected to solve a complex problem by structuring the hierarchy of criteria, the result-oriented party, and by selecting several considerations to develop the quality or priority (Saaty, 1993). Therefore, the researchers contended that the inventory of GHG emission in the transportation sector in Batu City was required to determine the appropriate adaptation and mitigation strategies related to GHG emission level reduction effort. 


\section{Literature review}

\subsection{Transportation}

Land transportation is the main consumer of fuel products. Motorized vehicles inland transportation convert fuel into mechanical energy and $40 \%$ of it is converted into heat which has an impact on increasing the temperature of the environment (Tanczos \& Torok, 2006). Each litre of fuel oil burned will emit about 100 grams of carbon monoxide, 30 grams of nitrogen oxide, $2.5 \mathrm{~kg}$ of carbon dioxide and various other compounds including sulfur (Hickman, 1999). Measures to reduce emissions from the transportation sector need to be carried out because the GHG emissions produced was predicted to be double in less than 10 years. This would cause transportation to have a major contribution to atmospheric air pollution because it contributed to GHG emissions (Dewan Nasional Perubahan Iklim, 2010).

\subsection{Adaptation and mitigation to climate change}

Adaptation is the development of a progressive pattern that is resistant to the effects of climate change and weather anomaly disruptions that occur today and as the anticipation in the future (Ridwan \& Chazanah, 2013). According to Setiawan (2010), adaptation is an important response to minimize hazards due to climate change. Adaptation plays a role in reducing the immediate impact of climate change that mitigation cannot do.

Mitigation is defined as efforts to prevent carbon release, increase carbon sequestration into forests or other carbon sinks, and slow down the effects of GHGs caused by the global warming (UNFCCC, 2005). Meanwhile, according to Slamet (2015), mitigation is an effort to suppress the causes of climate change, such as GHG and others so that they can be minimized or prevented.

\subsection{Analytical Hierarchy Process method}

AHP was first developed by Thomas L. Saaty, a mathematician from the University of Pittsburg, the United States in the 1970s. AHP is basically designed to capture people's perceptions related very closely to certain problems through procedures designed to select the best scale among various alternative sets. This analysis is intended to produce solution for a problem that does not have a structure, usually set to solve measurable problems (quantitative), problems that require opinion (judgment) in complex or unforeseen situations, and in situations where data, statistical information is minimal or not available and only qualitative data identified in nature based on perception, experience or intuition. AHP is also widely used in deciding many criteria, planning, resource allocation and in determining the priority strategies that players have in conflict situations (Suryadi \& Ramadhani, 1998).

\section{Methodology}

\subsection{Research method}

The measurement of GHG emission in transportation sector according to the number of vehicles and their average mileage is a bottom-up measurement to reduce the emission level of $\mathrm{CO}_{2}$ by transportation activities from the vehicles' fuel consumption. The researchers did the measurement using Equation (1) which compared the number of vehicles and their mileage, upon the total kilo meter of all vehicles. Dividing the total kilo meter of vehicles and the average consumption of a vehicle's fuel will show the amount of fuel consumption. Subsequently, the 
total consumption of fuel may be turned into $\mathrm{CO}_{2}$ through the application of certain emission factors of fuel per litre.

$$
E\left(\mathrm{CO}_{2}\right)=n \times \frac{\emptyset \text { Vehicle Kilometer }}{\emptyset \text { Fuel Consumption }\left(\operatorname{in} \frac{\mathrm{km}}{\mathrm{l}}\right)} \times \text { emission factor }_{\mathrm{a}}\left(\mathrm{kg} \frac{\mathrm{CO}_{2}}{\mathrm{~L}}\right)
$$

$\mathrm{E}\left(\mathrm{CO}_{2}\right)$ is the emission of $\mathrm{CO}_{2}, n$ is the number of vehicles, and EFA is the emission factor.

\subsection{GHG emission reduction scenarios}

The creation of the scenario has the purpose to be the alternative in reducing the GHG emission in Batu City based on the existing GHG emission produced. Such scenarios would be useful to figure out the reduction of emission as the consideration of alternative selection. The descriptions of scenarios in each sector are presented as follow.

Scenario 1 : The development of Intelligent Transport System (ITS) as communication and information technology applied in the facility and infrastructure to improve the quality of transportation service.

Scenario2 : The document application of Control upon Traffic Impact Analysis from the development of the activity centre, residence and infrastructure.

Scenario 3 : Parking Management Application provides convenience to achieve the purpose (entire accessibility).

Scenario $4 \quad$ : Reformation of Bus Rapid Transit (BRT) System using the bus with a special lane to increase the capacity of massive transport.

Scenario 5 : Rejuvenation of public transport by substituting the old public transportation with the new one to ensure the feasibility.

Scenario $6 \quad$ : Gasification of public transportation by converting the fossil fuel to gas fuel in public transportation by using converter kit.

Scenario $7 \quad$ : Training and socialization upon Smart Driving stimulating drivers to produce strategies to be efficient in fuel consumption.

\subsection{The determination of adaptation and mitigation strategies}

The determination of adaption and mitigation strategies are based on Batu City Spatial Plan during the period of 2010-2030, Long Term Development Plan of Batu City in the period of 2005-2025, and details of follow up activities of the Ministry of Transportation concerning National Action Plan for Greenhouse Gas Reduction based on Presidential Regulation of the Republic of Indonesia No. 61 of 2011. To determine the prioritized strategy selection of GHG, the researchers applied AHP method considering that it decomposed the strategies, provided the assessment by comparing each element of strategy decomposition result, and compiled the prioritized determination strategy that should be applied. Furthermore, the researchers used the questionnaire as the media in the AHP method to determine the relative degree of all alternative strategies. The overall process of prioritized vector measurement from each respondent's answer was analyzed through Super Decision program so that the priority of each 
answer based on the first and second stage question could be figured out. After figuring out the prioritized strategy, the researchers then may compile the chosen alternatives.

\section{Results and discussions}

\subsection{Inventory of GHG emission}

The measurement result of the $\mathrm{CO}_{2}$ total emission with $\mathrm{BAU}$ scenario produced by transportation in Batu City in 2030 is predicted to reach 2,072.64 Gg of $\mathrm{CO}_{2}$ including $\mathrm{CO}_{2}$ emission of vehicles ownership and tourist visit respectively amounted to $234,28 \mathrm{Gg}$ of $\mathrm{CO}_{2}$ and $1838,37 \mathrm{Gg}$ of $\mathrm{CO}_{2}$. Figure 1 denotes the growth of $\mathrm{CO}_{2}$ emission produced by the transportation sector with $\mathrm{BAU}$ scenario. The increase of $\mathrm{CO}_{2}$ emission from tourist visit significantly and continuously climbed up while the vehicle ownership shows gradual development trend. This was because of the tourism development in line with the development function of Batu City as a Tourism and Agropolitan City in East Java based on the spatial vision.

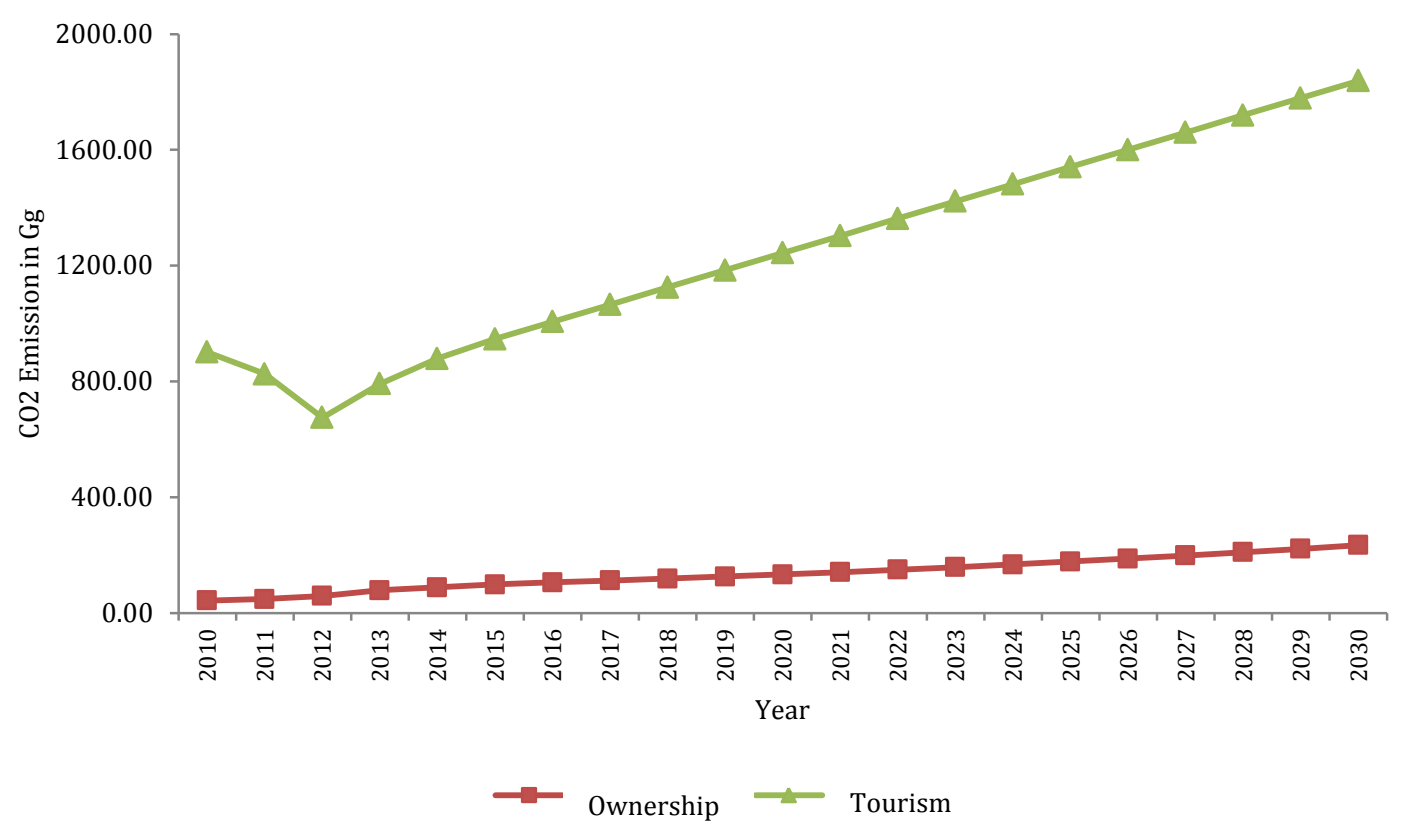

Figure 1. Graphic of $\mathrm{CO}_{2}$ emission produced by the transportation sector with $\mathrm{BAU}$ Scenario

\subsection{Reduction of GHG emission}

The measurement of GHG emission reduction in the transportation sector upon all scenarios showed that scenario 1 contributed the most significant emission reduction amounted to $-6.13 \%$ of all BAU scenarios in 2030 . Scenario 1 planned to apply the ITS leading it to provide clear information to users. As the consequence, service users could plan their trip more easily. Furthermore, it provided priority in a crossroad, so the traffic distraction within crossroad could be minimized to guarantee the accurate mileage. $\mathrm{CO}_{2}$ reduction was conducted by decreasing the length of unnecessary trip and improve the velocity to the optimal stage. Table 1 describes the recapitulation of achievement in the reduction of GHG emission in the transportation sector in Batu City. 
Table 1. The achievement of GHGs emission reduction of transportation in Batu City

\begin{tabular}{ccccccc}
\hline \multirow{2}{*}{ Condition } & \multicolumn{7}{c}{ Year } \\
\cline { 2 - 7 } & \multicolumn{2}{c}{2010} & \multicolumn{2}{c}{2020} & \multicolumn{2}{c}{2030} \\
\cline { 2 - 7 } & $\mathrm{Gg} \mathrm{CO}_{2}$ & $\%$ & $1,376.96$ & - & $2,072.64$ & - \\
\hline Scenario BAU & 943.68 & - & $1,292.55$ & -6.13 & $1,945.61$ & -6.13 \\
Scenario 1 & 943.68 & - & $1,374.89$ & -0.15 & $2,069.54$ & -0.15 \\
Scenario 2 & 943.68 & - & $1,326.63$ & -3.65 & $1,996.91$ & -3.65 \\
Scenario 3 & 943.68 & - & $1,368.72$ & -0.60 & $2,047.95$ & -1.19 \\
Scenario 4 & 943.68 & - & $1,376.84$ & -0.01 & $2,072.45$ & -0.01 \\
Scenario 5 & 943.68 & - & $1,376.72$ & -0.02 & $2,072.26$ & -0.02 \\
Scenario 6 & 943.68 & - & $1,363.88$ & -0.95 & $2,053.24$ & -0.94 \\
Scenario 7 & 943.68 & - & & & \\
\hline
\end{tabular}

\subsection{Determination of adaptation and mitigation strategies}

Upon the determination of alternative activities and criteria to reduce the GHG emission in the transportation sector, the researchers conducted the interview with the expert (expert judgment) and distributed questionnaires to collect various information on the alternative and criteria relating to the activity of GHG emission reduction. The interview was conducted to parties working on the Transportation Office of Batu City.

\subsubsection{Determination of prioritized adaptation strategy}

The hierarchy model of AHP in adaptation strategy upon the reduction of GHG emission in the transportation sector in Batu City is presented in Figure 2. In the chart, three levels of hierarchy: goal, criteria and alternatives are presented. The goal of AHP was to reduce the vulnerability of GHG emission in Batu City's transportation sector. The criteria which were applied to determine the prioritized adaptation strategy upon the reduction of the GHG emission vulnerability in the transportation sector were exposure, sensitivity and ability to adapt. The last hierarchy was the alternative for adaptation strategy upon the reduction of GHG emission in Batu City's transportation sector.

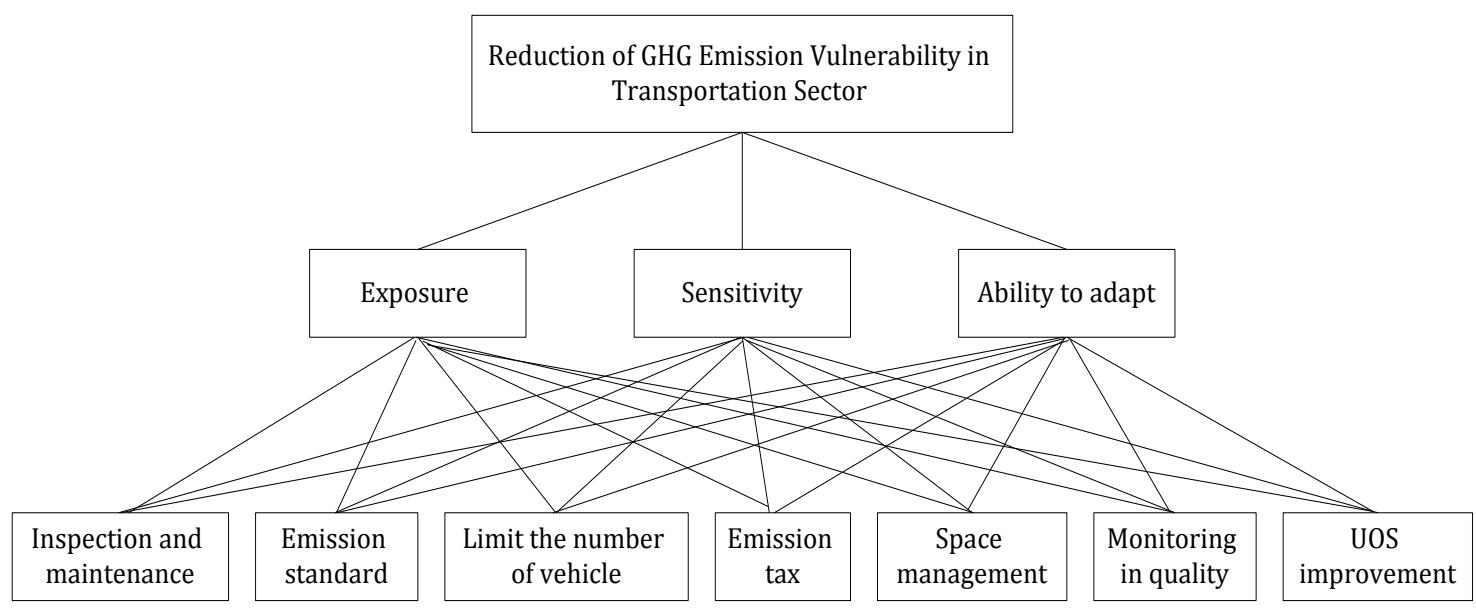

Figure 2. Analysis process of the hierarchy of adaptation strategy in the transportation sector 
Table 2. The result of weighting of adaptation strategy upon the reduction of GHG emission in Batu City's transportation sector

\begin{tabular}{lccc}
\hline \multicolumn{1}{c}{ Name } & $\begin{array}{c}\text { Normalized } \\
\text { By Cluster }\end{array}$ & Limiting & Rank \\
\hline Exposure Criteria & 0.53961 & 0.269807 & $1^{* * *}$ \\
Sensitivity Criteria & 0.29696 & 0.148481 & 2 \\
Ability to Adapt Criteria & 0.16342 & 0.081712 & 3 \\
Inspection and Maintenance alternative & 0.08486 & 0.042429 & 6 \\
Emission Standard alternative & 0.14702 & 0.073509 & 3 \\
Limitation of the number of vehicle & 0.11777 & 0.058886 & 5 \\
alternative & 0.07299 & 0.036494 & 7 \\
Emission Tax Alternative & 0.15976 & 0.079878 & 2 \\
Space Management Alternative & 0.14419 & 0.072093 & 4 \\
Air Quality Alternative & 0.27342 & 0.136711 & $1^{* * *}$ \\
UOS Improvement Alternative & & & \\
\hline
\end{tabular}

The result of qualifying for the adaptation strategy upon the reduction of GHG emission in Batu City's transportation sector is figured in Table 2. The result of weighting denoted that exposure, comprising the limiting weight amounted to 0.269807 which became the criteria with the greatest weight. In other words, the greater the GHG emission exposure in the transportation sector, the more difficult people's attempt to adapt with such condition. Therefore, the government's support to prevent such exposure by several alternative adaptation strategies in Batu City was obviously required. Based on the analysis, the researchers figured out that the best alternative was the improvement of UOS having the value of 0.136711 . The improvement of UOS in Batu City aimed to maintain the green space within the city especially the one located in the city centre to improve the quality of the environment. To improve the UOS other than the one with soil medium, there was also a mean to achieve the green space by growing the plant within the area of buildings known as Green Building. Green Building is a plan and design of the building by a process which puts concern in the environment and the efficient use of the resource in all life cycles of the building starting from the foundation, design, construction, residence, maintenance, renovation and building transformation (USEPA, 2006). The construction of the green building could be conducted in the density traffic area such as tourism object locations in Batu City.

\subsubsection{Determination of prioritized mitigation strategy}

The hierarchy model of AHP of mitigation strategy upon the reduction of GHG emission in the transportation sector is revealed in Figure 3. The goal of this study was to reduce the GHG emission in Batu City's transportation sector. The criteria are presented in the second level of the hierarchy. Five criteria were implemented in this AHP including air pollution, environmental cost, efficiency, sustainability and the ease of management. The last hierarchy was the subcriteria that implemented seven alternatives of the decision. Those were an intelligent transport system, traffic impact analysis, parking management application, relevant system reformation, public transport rejuvenation, public transport gasification and smart driving. 


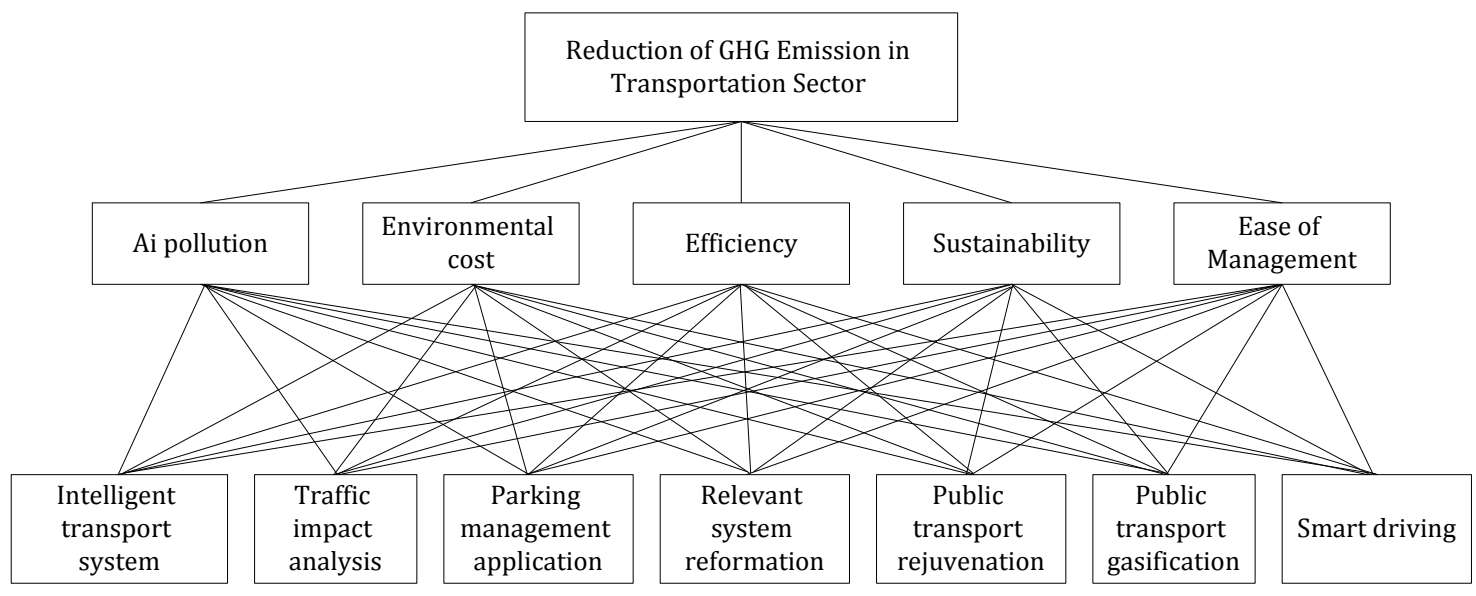

Figure 3. Analysis process of hierarchy in mitigation strategy within the transportation sector

Table 3. Result of weighing in mitigation strategy upon the reduction of GHG emission in Batu City's transportation sector

\begin{tabular}{lccc}
\hline \multicolumn{1}{c}{ Name } & $\begin{array}{c}\text { Normalized } \\
\text { by cluster }\end{array}$ & Limiting & Rank \\
\hline Investment Cost Criteria & 0.17020 & 0.085101 & 5 \\
Efficiency Criteria & 0.17228 & 0.086141 & 4 \\
Sustainability Criteria & 0.20263 & 0.101317 & 3 \\
Ease of Management Criteria & 0.22433 & 0.112167 & 2 \\
Air Pollution Criteria & 0.23055 & 0.115275 & $1^{* * *}$ \\
Traffic Impact Analysis Alternative & 0.16921 & 0.084607 & 2 \\
Alternative Public Transport Gasification Criteria & 0.12155 & 0.060774 & 5 \\
ITS Alternative & 0.07913 & 0.039564 & 7 \\
Parking Management Implementation Alternative & 0.13639 & 0.068194 & 4 \\
Public Transport Rejuvenation Alternative & 0.22544 & 0.112718 & $1^{* * *}$ \\
Transit System Reformation Alternative & 0.11960 & 0.059802 & 6 \\
Smart Driving Alternative & 0.14868 & 0.074340 & 3 \\
\hline
\end{tabular}

The result of weighting for mitigation strategy upon the reduction of GHG emission in Batu City' transportation sector is illustrated in Table 3. The result shows that the criteria with the greatest weight were air pollution, with limiting weight amounted to 0.115275 . In other words, the greater the air pollution produced by the transportation sector, the greater the effort needed to reduce the GHG emission conducted. Therefore, the government's support to prevent the air pollution emitted by the transportation sector through the application of several mitigation alternative strategies in Batu City transportation sector was required. From the result of the alternative weighting, the researchers found out that public transport rejuvenation owned the biggest alternative weight, with limiting weight amounted to 0.112718 . As matter of fact, public transport rejuvenation was one of the government's policies to solve people's complain relating to their demand in the improvement of public service in the transportation sector, especially urban transport. This policy was supported by Law Number 22 of 2009 concerning Road Traffic and Transportation as well as the Decision of Minister of Transportation Number 35 of 2003 on the implementation of public transportation for people by public vehicle. However, prioritized public transport rejuvenation within mitigation strategy upon the reduction of GHG emission in 
the transportation sector, based on the measurement of GHG emission reduction, was projected to contribute only $0.01 \%$ in 2030 . This was because the number of private vehicles more dominated the area compared to the number of available public transportations. Therefore, the policy regulating public transport rejuvenation should be supported and combined with a strategy of BRT transit system that was able to reduce the GHG emission up to $-1.19 \%$ in 2030 .

\section{Conclusion}

After analyzing the data, the researchers concluded that the GHG emission with BAU scenario in 2030 within transportation sector reached 2.072,64 Gg of $\mathrm{CO}_{2}$ while the greatest emission reduction was affected by the application of Intelligent Transport System, which was amounted to $-6.13 \%$. Most importantly, the prioritized adaptation and mitigation strategies in the transportation sector respectively were the UOS improvement and public transport.

\section{Acknowledgement}

We would like to deliver our greatest gratitude to the Government of Batu City for permitting us to conduct the research in that region. Also, we would like to thank the Transportation Office as well as the Central Bureau of Statistics of Batu City for providing us with relevant data for this research.

\section{References}

Adak, P., Sahu, R., \& Elumalai, S. P. (2016). Development of emission factors for motorcycles and shared auto-rickshaws using real-world driving cycle for a typical Indian city. Science of the Total Environment, 544, 299-308.

BAPPENAS. (2012). Modul Pelatihan Inventarisasi GRK Bidang Pengelolaan Limbah. Jakarta: Badan Perencanaan Pembangunan Nasional.

Boedoyo, M. S. (2008). Penerapan teknologi untuk mengurangi emisi gas rumah kaca. Jurnal Teknik Lingkungan, 9(1), 9-16.

Budiyanto, M. A. K. (2010). Teknik Pengembangan Industri Ekotourisme Kota Batu Provinsi Jawa Timur dalam Perspektif Kebijakan. Jurnal Teknik Industri, 11(1), 35-41.

Dewan Nasional Perubahan Iklim. (2010). Peluang dan Kebijakan Pengurangan Emisi Sektor Transportasi. Jakarta.

Hickman, A. J. (1999). Methodology for Calculating Transport Emissions and Energy Consumption. UK: Transport Research Laboratory.

Klein, R. J. T., \& Huq, S. (2007). Inter-Relationships Between Adaptation and Mitigation. Fourth Assessment Report (AR4): Contribution of Working Group II to the Fourth Assessment Report of the Intergovernmental Panel on Climate Change. Cambridge: Cambridge University Press.

Nurhidayati, S. E. (2009). Sistem Pariwisata di Agropolitan Batu. Media Masyarakat, Kebudayaan Dan Politik, 22(1), 76-85.

Ridwan, \& Chazanah, N. (2013). Penanganan Dampak Perubahan Iklim Global pada Bidang Perkeretaapian Melalui Pendekatan Mitigasi dan Adaptasi. Jurnal Teoretis dan Terapan Bidang Rekayasa Sipil, 20 (02), 133-142. 
Saaty, T. L. (1993). Multi-criteria decision making: the analytic hierarchy process. USA: RWS Publication.

Setiawan, R. (2004). Penerapan Manajemen Transportasi Kampus Sebagai Upaya Mengurangi Penggunaan Mobil (Studi Kasus Universitas Kristen Petra). Simposium VII FSTPT, Universitas Parahyangan, 11 September 2004, 1-10.

Slamet, B. (2015). Analisis Kebijakan Land Use Land Use Change Forestry (LULUCF) dan Skenario Mitigasi dan adaptasi Perubahan Iklim. Research Gate, Juli 2015.

Suryadi, K., \& Ramdhani, M.A. (1998). Sistem Pendukung Keputusan: Suatu Wacana Struktural Idelisasi dan Implementasi Konsep Pengambilan Keputusan. Bandung: Remaja Rosdakarya Offset.

Tanczos, K., \& Torok, A. (2006). Estimation Method for Emission of Road Transport, Department of Transport Economics. Journal of Periodica Polytechnica ser. Transp. Eng, 03, 93-100.

UNFCCC. (2005). Kyoto Protocol to the United Nations Framework Convention on Climate Change. Germany.

USEPA. (2006). Greenhouse gas inventory. The USA.

Zhang, X., Liu, P., Li, Z., \& Yu, H. (2013). Modelling the effects of low-carbon emission constraints on mode and route choices in transportation networks. Procedia-Social and Behavioral Sciences, 96, 329-338. 